\title{
СТАНОВЛЕННЯ НАВЧАЛЬНО-НАУКОВОГО ІНСТИТУТУ МОРФОЛОГІї
}

\author{
К. С. Волков
}

ДВНЗ “Тернопільський держсавний медичний університет імені І. Я. Горбачевського МОЗ Украӥни”

\section{DEVELOPMENT OF EDUCATIONAL SCIENTIFIC INSTITUTE OF MORPHOLOGY}

\author{
K. S. Volkov \\ SHEI "Ternopil State Medical University by I. Ya. Horbachevsky of MPH of Ukraine"
}

\begin{abstract}
У статті висвітлено основні напрямки діяльності Навчально-наукового інституту морфології.
\end{abstract}
Article adduces the main trends of activity of educational-scientific studying institute of morphology.

Вступ. Згідно з Концепцією розвитку Тернопільського державного медичного університету імені I. Я. Горбачевського теоретичні кафедри об'єднані в чотири навчально-наукові інститути, що розміщені у відповідних корпусах університету. Метою створення інститутів було підвищення ролі органів громадського самоврядування у керівництві підрозділами. Щорічно кожен директор ННІ звітується на вченій раді університету або факультету за виконану підпорядкованим йому підрозділом роботу.

Основна частина. Навчально-науковий інститут морфології створений згідно з наказом ректора 15 липня 2005 року. Робота інституту координується вченою радою під головуванням директора проф. К. С. Волкова. Щорічно складаються плани роботи, регулярно проводяться засідання вченої ради та оперативні наради інституту. Порядок денний тапроекти рішень вченоїради розміщуються на Web-сторінці університету.

Базою інституту є морфологічний корпус, де розташовано три кафедри: анатомії людини, патологічної анатомії з секційним курсом та судовою медициною, гістології та ембріології. Матеріальна база включає лекційний зал, навчальні аудиторії, бібліотеку 3 читальним залом, наукову лабораторію, музеї, допоміжні приміщення.

Бібліотека інституту достатньо укомплектована навчальною літературою, обладнана 23 новими комп’ютерами, які підключені до Інтернету, читальний зал працює згідно з затвердженим графіком з 9 год до 21 год 30 хв. Це значно покращило якість самостійної роботи студентів, дозволило проводити тестування студентів за системою "Moodle".

(с) К. С. Волков

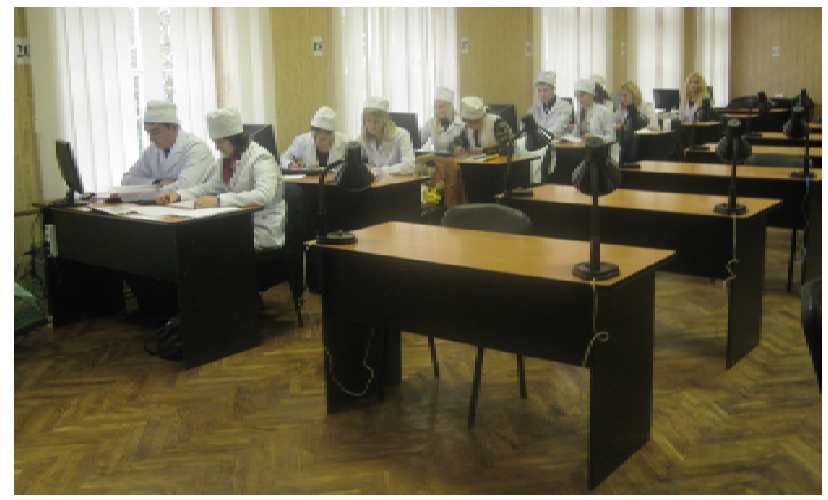

Фото 1. Читальний зал, обладнаний сучасними комп'ютерами.

В лекційній аудиторії встановлена нова мультимедійна система, що значно покращило якість демонстрації лекторами презентацій їх матеріалів.

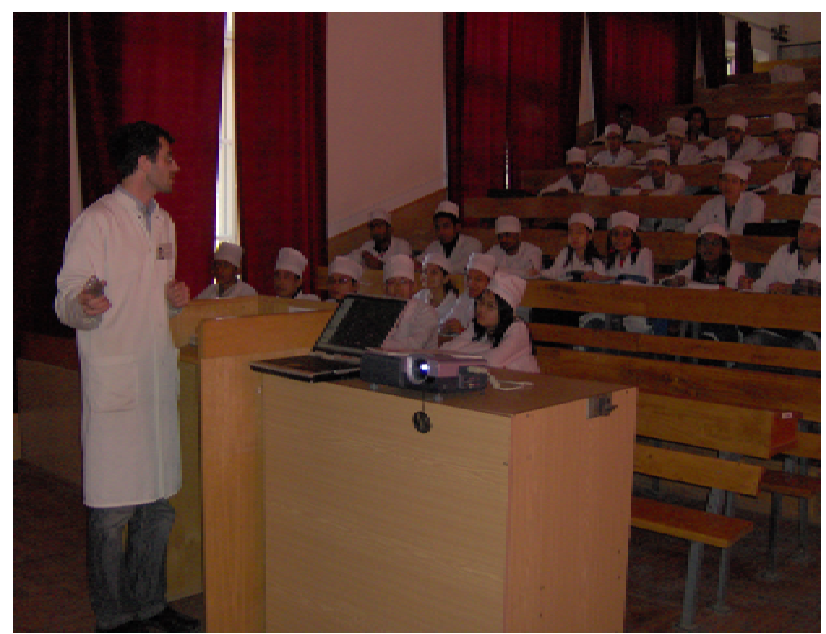

Фото 2. Лекційна аудиторія інституту морфології. 
На всіх кафедрах інституту за останні роки широко впроваджені нові технології навчання. Для цього використовуються відповідні прилади і оснащення. Для покращення технічного забезпечення навчального процесу придбано 70 світлооптичних мікроскопів, 10 плазмових телевізорів і 10 комп'ютерів, 6 відеокамер, 8 негатоскопів, 5 пластикових скелетів. Таким чином, на сьогодні використовується в навчальному процесі: кафедра гістології - 9 відеосистем, кафедра патологічної анатомії - 6 відеосистем, кафедра анатомії людини - 3 відеосистеми та 16 негатоскопів.

На кафедрі гістології в навчальних кімнатах кожне робоче місце викладача обладнане відеосистемою (мікроскоп, відеокамера, телевізор, комп'ютер), за допомогою якої студентам демонструються гістологічні препарати, відеофільми, здійснюється контроль знань студентів.

На кафедрі анатомії людини у секційних залах негатоскопи розміщені на всіх робочих місцях, що дало змогу широко впровадити Z-систему навчання студентів. На практичних заняттях широко використовуються рентгенограми і томограми. Створено 15 ком-



плектів по 5 папок (в папці по 10 МРТ-грам на кожний модуль). Загальна кількість 750 МРТ-грам. На кафедрі патологічної анатомії з секційним курсом і судовою медициною у навчальному процесі Z-система передбачає опрацювання студентами макропрепаратів $\mathrm{i}$ мікропрепаратів, а також опанування принципів написання протоколів розтинів. Крім того, на практичних заняттях, використовуючи клінічні і морфологічні дані, студенти опановують принципи клініко-морфологічного аналізу, навички формулювання діагнозу. Розроблено формат доказовості, який включає класифікацію хвороб за МКХ-10, частоту захворюваності, а також морфологічне підтвердження патології, особливо при специфічних інфекційних захворюваннях.

У зв'язку із збільшенням груп, які одночасно навчаються на кафедрах інституту, в останні два роки виникла проблема їх розміщення. Тому оперативно були здійснені ремонтні роботи у цокольних приміщеннях корпусу, підготовлені 3 нові навчальні кімнати, що дало змогу додатково навчати 10 груп студентів. Нові навчальні кімнати оснащені якісними меблями, навчальними дошками, демонстраційною технікою.

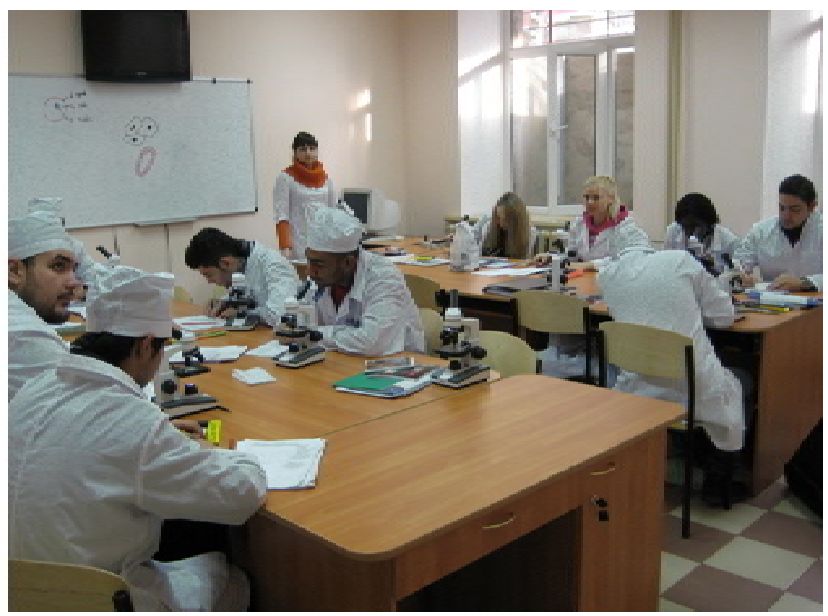

Фото 3. Нові навчальні кімнати кафедри анатомії людини та гістології.

У навчальному процесі широко використовується музей атанатомічних препаратів, музей патанатомічних препаратів та музей курсу судової медицини. За останні роки проведена повна реставрація препаратів музеїв, оновлені вологі препарати, виготовлені таблички трьома мовами.

Таке сучасне технічне забезпечення навчального процесу і нові технології навчання дозволили провести за останні 10 років на базі інституту 3 рази наради завідувачів кафедр гістології та гістології 12 рази завідувачів кафедр анатомії людини медичних вузів України.

Велику увагу в інституті приділяють питанню підготовки кадрів, яке обговорюється на засіданнях ка- федр, оперативних нарадах та вченій раді інституту. Всі кафедри повністю укомплектовані викладачами, але на даний час існує проблема якісного їх складу. Проте всі молоді викладачі запланували і активно працюють над виконанням дисертаційних робіт.

Не сходить 3 порядку денного питання опанування викладачами іноземних мов, але воно успішно вирішується. Тільки за 2010-2011рр. пройшли сертифікацію 6 викладачів кафедр інституту, ще 4 викладачі навчаються на курсах іноземних мов.

Кредитно-модульна система впроваджена на всіх кафедрах інституту. Новим $€$ те, що кафедра гістології перейшла з 3 модулів на 2-модульне навчання згідно 3 рекомендаціями опорної кафедри. Навчання на кафедрі 
Фото 4. Анатомічний та патологоанатомічний музеї після реставрації.

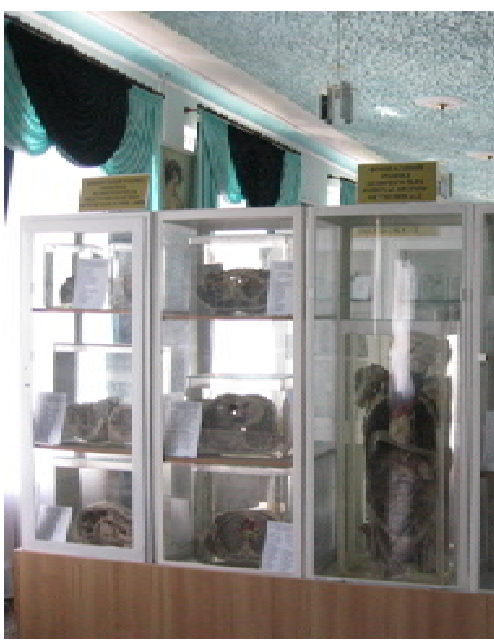

анатомії людини також проводиться за 3-модульною системою - один семестр один модуль. Вивчення патологічної анатомії за кредитно-модульною системою проводиться 3 використанням 2 модулів.

На кафедрах практичні заняття зі студентами проводяться відповідно до вимог, рекомендованих навчальною частиною, методрозробок для викладачів і студентів. Вагомим є те, що методрозробки для студентів оновлюються кожний навчальний рік. Методика проведення занять зорієнтована, в першу чергу, на засвоєння знань і навичок, які необхідні для практичної роботи лікаря.

Велика увага при організації навчального процесу приділяється Web-сторінкам кафедр. На них розміщені робочі програми, календаризовані-тематичні плани, розклади занять, відробок і інші навчальнометодичні матеріали. Кафедри постійно працюють над поновленням матеріалів на допомогу студентам до практичних занять, презентацій лекцій.

Колективи кафедр в останні роки працювали і над розширенням бази тестових завдань, їх оновленням, відповідно до рекомендацій навчальної частини. Банк тестових завдань кожної кафедри складає 250 тестів на кожне практичне заняття 3 попереднього тестування за системою “Moodle”. Систематично проводиться оновлення тестів і до незалежного семестрового тестування.

Для щоденного контролю знань студентів викладачами кафедр створені контролюючі програми. Оцінювання знань студентів проходить із врахуванням виконання практичної частини заняття, участі у семінарському обговоренні матеріалу і виконання контролюючих завдань. Для покращення підготовки і здачі практичних навичок створені відеофільми 3 усіх розділів предметів.

Самостійна позааудиторна робота студентів на кафедрах організована під керівництвом чергових вик-

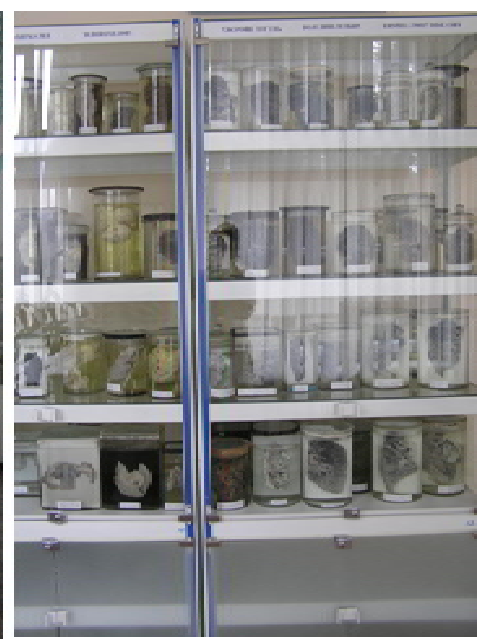

ладачів з 15.30 до 21.30 год згідно з графіками, які розміщено на дошках оголошень та на Web-сторінках кафедр. На кафедрі анатомії людини студенти мають можливість вивчати комп'ютерні томограми, працювати з вологими мікропрепаратами, відпрепарованими трупами та препаратами в музеї кафедри. При необхідності черговий викладач надає консультації та допомагає вивчати складні питання з різних розділів предмета. Працівниками кафедри патоморфології 3 секційним курсом і судовою медициною видано методичний посібникз самостійної позааудиторної підготовки, який включає 18 тем 3 патологічної анатомії.

В інституті функціонує наукова загальноінститутська лабораторія, яка включає - морфогістохімічну, електронномікроскопічну, морфометричну і спектрофотометричну кімнати. За останні роки значно покращилось матеріальне забезпечення наукової лабораторії. Проведений ремонт і модернізація атомноадсорбційного спектрофотометра, поставлено програмне забезпечення, відпрацьовані методики досліджень. Встановлена нова цифрова система виводу зображення високої роздільної здатності для електронного мікроскопа ПЕМ-125К, проведений профілактичний ремонт приладу. У грудні 2011 року придбаний новий лабораторний мікроскоп з сучасним програмним забезпеченням.

При виконанні морфологічних досліджень використовуються як загальні методики, так і спеціальні: гістохімічні, імуногістохімічні, біохімічні. Широко використовуються макрометричні, масометричні, морфометричні методи досліджень. Постійно застосовуються електронномікроскопічні та електронноморфометричні методики досліджень.

Одним із пріоритетних напрямків наукової роботи інституту є організація наукових досліджень і впровадження їх у клінічну практику. Так, згідно з наявними на кафедрах інституту планами, проводяться 

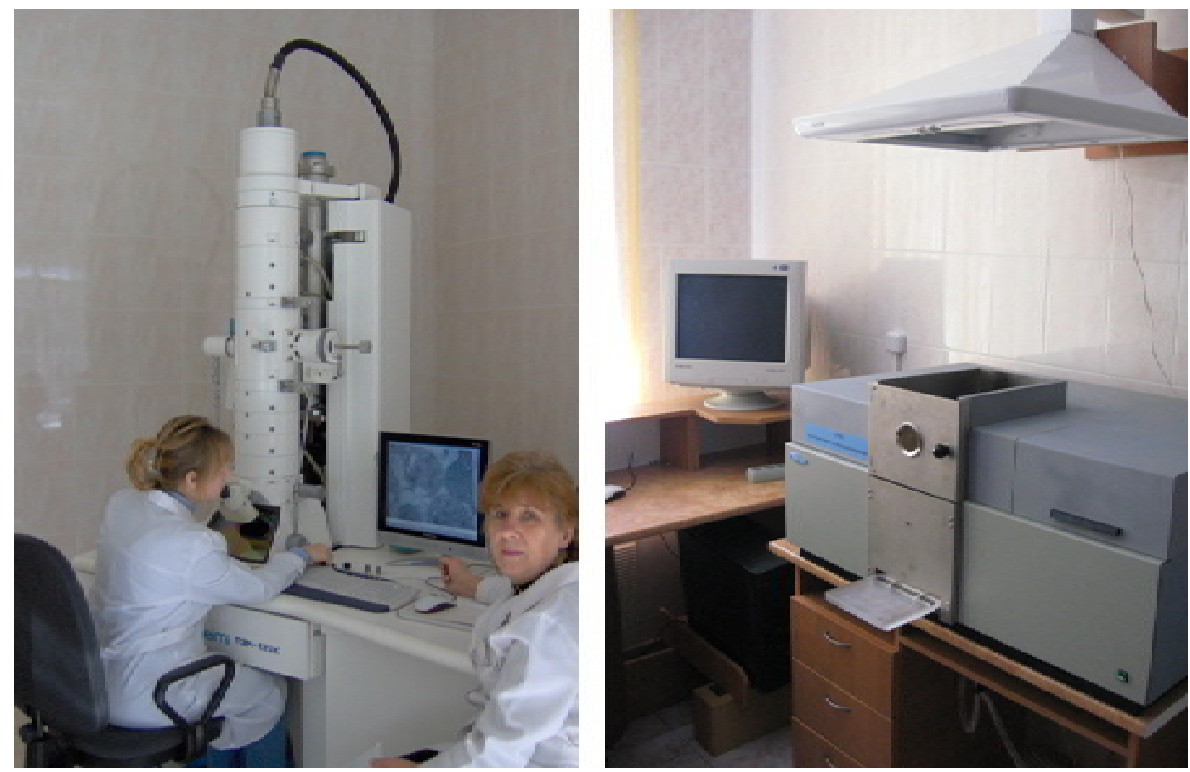

Фото 5. Наукова лабораторія інституту. Електронний мікроскоп з програмним забезпеченням, атомно-адсорбційний спектрофотометр. дослідження, щодо морфологічного обгрунтування доцільності нових методів лікування опікової хвороби, морфологічної діагностики хвороб серцево-судинної системи, шлунково-кишкового тракту, а також впливу фізичних факторів на адаптаційні процеси кісткової системи організму.

За останні 5 років науковці інституту морфології виконали 3 комплексні НДР, а у 2011 році запланували загальноінститутську НДР “Ремоделювання кровоносного русла органів і тканин при різних патологічних станах в експерименті”.

За науковими результатами цих НДР виконані і захищені одна докторська і 11 кандидатських дисертаційних робіт. Співробітниками інституту опубліковані за останні 5 років 219 статей, 266 тез, зроблено 107 доповідей на наукових форумах. Отримано 11 патентів, оформлені 4 інформаційних листи та 2 нововведення.

Співробітники кафедр інституту щорічно проводять науково-практичні конференції. За останні 5 років організовано 6 конференцій, одна 3 них “Актуальні проблеми морфологіï” була присвячена 70-річчю заслуженому діячу науки і техніки України, професору Я. І. Федонюку- 2010 р.

Наукова робота студентів-гуртківців на всіх кафедрах інституту проводиться згідно з планами і існуючими в університеті програмами, вони систематично беруть участь у різноманітних наукових форумах. Так, у II турі Всеукраїнського конкурсу наукових робіт у галузі “Теоретична медицина” у різні роки займали призові місця: 1 місце - студент медичного факультету Р. Кохан, 2 місце - студентка медичного факультету Х. Похила, 3 місця - студентка стоматологічного факультету I. Дацко та студенти медичного факультету М. Герасим'юк і В. Бабчишин.
Колективи кафедр інституту успішно працюють над підготовкою і виданням навчально-методичних матеріалів для потреб навчального процесу. Найбільш вагомими з них підручники: “Функціональна анатомія”, 2007 р.; “Основи медичних знань”, 2011 р.; навчальні посібники: “Анатомія людини з клінічним аспектом”, 2009 р.; “Патоморфологія”, 2009 р.

Розроблений перспективний план розвитку ННI морфології на 2012 - 2017 н. р., який передбачає:

- закінчення ремонту цокольних приміщень морфологічного корпусу;

- дооснащення навчальних кімнат всіх кафедр комп’ютерами з відеосистемами;

- забезпечення і впровадження в навчальний процес сучасних анатомічних муляжів і пластинатів;

- поповнення наявної бази навчальних відеофільмів, електронних підручників і атласів і широке використання їх у навчальному процесі;

- поповнення експозицій музеїв кафедр анатомії людини і патологічної анатомії;

- підвищення рівня наукових досліджень, розширення і удосконалення морфологічних методик.

Висновок. У створеному Навчально-науковому інституті морфології успішно реалізуються положення Концепції розвитку Тернопільського державного медичного університету імені І. Я. Горбачевського. Покращення матеріально-технічної бази кафедр інституту дозволило успішно впровадити Z-систему та методику “єдиного дня” навчального процесу за кредитно-модульною системою. У загальноінститутській науковій лабораторії, оснащеній сучасними приладами, на високому рівні проводяться наукові дослідження фундаментального і прикладного характеру. 